The attempt to isolate Chile reminds me of a similar attempt to isolate Brazil a few years ago. Although the Brazilian government is still very authoritarian, scandals are no longer caused when foreign scientists are invited to Brazil. Moreover, the great majority of the Brazilian scientists are opposed to the military government (although many of them returned to Brazil after the military took over, because of very important salary rises).

The main victims of this isolation, at least in the case of Chile, were the common people and more specifically scientists and students. The Chilean government, less stupid than generally thought, has used the argument of "all against us" as a powerful nationalistic tool. It seems aberrant to me that while scientists from all over the world are being persuaded from going to Chile, a superpower, which originated and supported the isolation campaign, is engaged in an exchange of political prisoners with the Chilean government, giving a tremendous popular credit to the military junta inside the country. A visit of all Nobel laureates to Chile, would not strengthen the military as the exchange of prisoners did.

Attending an international scientific meeting or visiting a Chilean or Argentinian university is not synonymous with supporting the military government of these countries. On the contrary it is a unique opportunity to contact scientists and students and to encourage and help them to overcome the scientific and moral isolation they suffer.

We have to remember the case of Spain, a country which until a few years ago had the same type of government as Chile and Brazil now have. As long as it was isolated from the world no hope of ending the dictatorship existed. As more and more foreigners entered the country, an irreversible flow towards democracy started.

No tourist boom can be expected in Chile or Argentina, but scientists and academics passing through can be an indispensable link with students and scientists. Without this bond, they may be convinced by the chauvinistic arguments used by the government each time a world campaign is organised against it.

This is a plea not to support the South American dictatorships or to ease the criticisms against them but to maintain a link between their scientific communities and the rest of the world. This may be the unique possibility of keeping alive the result of years of effort, and the only hope of evolution towards the revival of democracy in these countries.

Simon LitVak

University of Bordeaux France

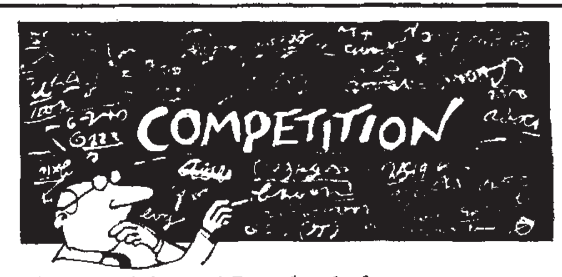

Competition 15 asked for an appropriate quote for our front cover. A good varied entry with an honourable mention to D. Irwin (Boston) for "Pereant qui ante nos nostra dixerunt" (May those perish who have said our things before us). But $£ 10$ goes to the Mammalian Development Unit, University College, London

\section{Technik or technics}

Sir,--On most topics, I would not set out to disagree with those who write to support me. However the question is too important to let go: it concerns the separateness of the German-language notion of a third culture of Technik.

Rey and I (1 September, page 2) argued that the idea of Technik represents a missing concept in English, whereas Cavalier-Smith (20 October, page 646) would like us to follow Lewis Mumford instead and revive the English word "technics". We avoided "technics" because Mumford got things very wrong in the book referred to, Technics and Civilisation.

Notably he argued for a distinction between the "neotechnics" of the age since about 1880 or so, and the "paleotechnics" which went before. Of the period just before neotechnics, he wrote that its inventions "came into existence, for the most part, without its [science's] direct aid"; whereas later in the "neotechnic phase, the main initiative comes, not from the ingenious inventor, but from the scientist who establishes the general law: the invention is a derivative product'.

Detailed investigation does not support this viewpoint, or the distinction between ages of manufacture on which Mumford's thesis is founded; science has always influenced manufacture, but never controlled it. Neither does detailed investigation support the viewpoint of R. J. Forbes, the author of Man the Maker (1950, Shuman), another hero of the historians of "technology". He writes his subject up, most misleadingly, as an account of the exploits of "applied science" through the "conquest of nature". A reliable book of the influence of Technik on the culture has yet to be written.

I am absolutely at one with CavalierSmith, however, that there is only harm to be done to science in the long term, through a blurring of the distinction between science and the technical who communally turned up: "Is this," I cried, "the end of prayer and preaching? Then down with pulpit, down with priest, and give us Nature's teaching!" (Whittier)

Competition 16. To the uninitiated, many scientific pictures are ambiguous : a section through a cell could equally be a slice of a lunar rock. Readers are invited to give a misleading caption to any picture that has appeared in, or on the cover of, a recent Nature. $£ 10$ to the winner. Entries to Competition 16, Nature, 4 Little Essex Street, London WC2 by 1 February 1978.

functions of manufacture. One vehicle for this harm has been the ghastly construction called "technology"; the only "-ology" in history to make useful, bulky artifacts as a primary output, a word which outsiders to manufacturing use when they want to hide their ignorance of it.

London, UK

M. FORES

\section{Sunflower's siesta}

Sik,-Observations on the sunflower's night life (8 September, page 102) prompt me to put on record a piece of its daylight behaviour which I have never seen described before. In Turkey, in July this year, I consistently saw that at $1 \mathrm{pm}$ on bright days the flowers all faced the sun but by $2.30 \mathrm{pm}$ all heads had turned away and faced north. At about $5 \mathrm{pm}$ they again began to face the evening sun and ended the day facing west.

Perhaps even the sunflower finds the Turkish afternoon summer sun a bit hot and has a thermal switch overriding the sun-tracking mechanism, so that it can have a siesta. Is the siesta phenomenon unusual, or do sunflowers always behave like this in hotter climates?

Torino, Italy

ROBERT G. MiINE.

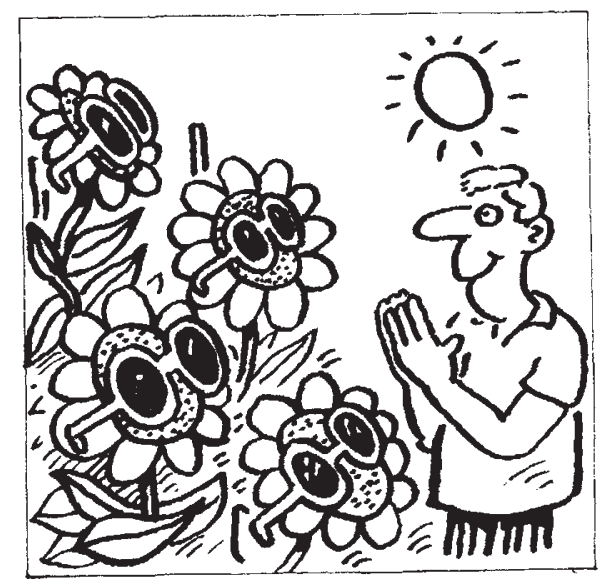

